\title{
Espertos ou Malandros: Como Pequenos Empresários e Vendedores Justificam Práticas Lesivas
}

\author{
Rodolfo Jakov Saraiva Lôbo. ${ }^{1}$ \\ Daniel Rodriguez de Carvalho Pinheiro ${ }^{2}$
}

Esperto, Malandro e Trapaceiro. Essas palavras guiarão todo o escopo do trabalho, termos que estão presentes no senso comum da sociedade brasileira. Expressões que revelam significados e explicações para ações realizadas também no cotidiano das empresas e dos consumidores. Essas palavras estão inseridas no seio da cultura nacional. "A cultura é um dos pontos-chave na compreensão das ações humanas, funcionando como padrão coletivo que identifica os grupos, suas maneiras de perceber, pensar, sentir e agir"' (Pires; Macêdo, 2006, p. 83).

Há muito tempo, a cultura nacional e a cultura organizacional são temas bastante discutidos no meio acadêmico, principalmente na relação que a cultura organizacional influencia o comportamento dos indivíduos e, consequentemente, dia a dia das organizações.

\footnotetext{
${ }^{1}$ Doutorando em Administração de Empresas pela Escola de Administração de Empresas de São Paulo (EAESP) da Fundação Getúlio Vargas (FGV). Mestre em Administração pela Universidade Estadual do Ceará (Uece), Especialista em Docência do Ensino Superior pela Faculdade Leão Sampaio e Graduado em Administração pela Faculdade Leão Sampaio. Tem experiência na área de ensino, administração e de pesquisas acadêmicas e gerenciais, atuando principalmente nos seguintes temas: Administração Geral, Administração Intercultural, Cultura Organizacional, Teoria das Organizações e Estudos Organizacionais.

${ }^{2}$ Graduado em Arquitetura e Urbanismo pela Universidade Federal do Ceará (1979), doutor em Sociologia pela Universidade Federal do Ceará (2000). Pós-Doutorado pela ESALQ / Universidade de São Paulo (2012). Professor adjunto da Universidade Estadual do Ceará e da Universidade de Fortaleza. Tem experiência na área de Arquitetura e Urbanismo, com ênfase em Planejamento Estratégico. Trabalha com Projeto Arquitetônico , Desenvolvimento, Economia Política e Gestão Territorial. Estuda Epistemologia, Métodos e Técnicas de Pesquisa e Gestão da Informação. Ensina Métodos e Técnicas de Pesquisa e Epistemologia.
}

Brasiliana - Journal for Brazilian Studies. Vol. 2, n.2 (Nov 2013). ISSN 2245-4373. 
Segundo Chu e Wood Jr. (2008), grande parte dos estudos que tem interesse em observar os impactos da cultura nacional na gestão das empresas se apoia em trabalhos sobre a formação histórica, cultural, social e econômica do país.

No Brasil, a cultura é bastante diversificada. Freitas (1997) identificou alguns traços que caracterizam a sociedade brasileira para uma análise organizacional. Os traços são: Hierarquia; Personalismo, Malandragem, Sensualismo e Aventureiro.

Pelo traço da Malandragem, objeto de estudo do presente trabalho, em uma sociedade marcada por diferenças, sendo hierarquizada e personalista como vimos anteriormente, a sociedade brasileira procura campo intermediário entre o impessoal e o pessoal. Um campo em que se busquem identificações com o outro por meio do qual se identifica um benefício como a religião, um time de futebol, um gosto em comum, fazendo com que o outro o favoreça, beneficiando-o de alguma forma, ou seja, dando um "jeitinho". O malandro seria um especialista na arte do "jeitinho". Flexibilidade e adaptabilidade como meio de navegação social é uma característica marcante do malandro (Freitas, 1997).

O investigador já havia realizado um estudo quali-quantitativo (quantum) sobre o tema, nas cidades de Fortaleza, Juazeiro e Sobral, onde a escala foi colocada em prática, tendo sido entrevistados 53 pequenos empresários ${ }^{3}$.

O grande achado da pesquisa foi identificar que os pequenos empresários entrevistados, naquela ocasião, tenderam a reconhecer a trapaça quando afeta diretamente o indivíduo; já no sentido oposto, quando afeta a coletividade, tendem a não interpretar essas ações como trapaça. Não há uma clareza de definição. O que pode ser uma indicação da relativização da prática reprovável (Pinheiro et. al., 2010).

\footnotetext{
${ }^{3}$ A pesquisa foi apresentada no VI Encontro de Estudos sobre Empreendedorismo e Gestão de Pequenas Empresas, no ano de 2010.
}

Brasiliana - Journal for Brazilian Studies. Vol. 2, n.2 (Nov 2013). ISSN 2245-4373. 
Neste contexto, foi formulado o seguinte problema da pesquisa: Como os pequenos empresários e vendedores do varejo de pequeno porte definem práticas lesivas recorrentes?

Com isto, o objetivo da pesquisa é: Verificar se o pequeno empresário justifica práticas que em si e por si são delitos. O campo para realização da pesquisa foi o comércio varejista de pequeno porte das regiões metropolitanas de Fortaleza e do Cariri, ambas no estado do Ceará. Os sujeitos da investigação foram pequenos empresários e vendedores do varejo de pequeno porte.

Para tanto, foram definidos como objetivos específicos deste estudo:

1. Associar as respostas em comportamentos que lesam a Coletividade e que lesam a pessoa;

2. Verificar se há diferenças de percepção entre a Região Metropolitana de Fortaleza e a Região Metropolitana do Cariri;

3. Identificar se há diferenças de percepção entre pequenos empresários e vendedores;

4. Verificar se existem percepções distintas quando se analisam as questões tendo como base as características de nível de escolaridade.

O estudo é empírico-analítico e tem como proposta natureza descritiva, pois analisará a percepção de pequenos empresários e vendedores do varejo de pequeno porte com relação a atos ilícitos em consonância com a fundamentação teórica da pesquisa.

A escolha da categoria malandragem tem suas razões. O malandro é um personagem cuja sobrevivência depende de pequenos delitos e espertezas descritas na canção de 1959, na Subida do Morro, de Moreira da Silva e Ribeiro Cunha; em Homenagem ao Malandro, de Chico Buarque de Holanda (1977); ou no livro Carnavais, Malandros e Heróis, de Roberto da Matta (1997). 
Textos acadêmicos tratam do tema como é o caso da tese de doutorado em Gestão de Empresas de Roberto Pinto (2008), Evasão Fiscal e Estratégia Empresarial: a percepção de empresários brasileiros, onde discute práticas que seriam formas de malandragem praticadas nos negócios.

Cientes que os estudos mencionados acima constituem evidências teóricas do tema, considera-se oportuno formatar as seguintes hipóteses:

H1: Malandragem é um traço da cultura e da moral brasileira, portanto, maior parte das respostas está concentrada na opção malandragem.

$\mathrm{H}_{2}$ : Empresário e vendedor tendem a reconhecer a trapaça quando ela prejudica uma pessoa (trabalhador e cliente) e não tem a mesma clareza moral quando ela prejudica a coletividade (Pinheiro et al.,2010).

$\mathrm{H}_{3}$ : Não há diferença significativa entre as respostas da RMF e da RMC sobre as práticas lesivas recorrentes (trapaças), portanto, não há nesse caso, influência da cultura regional (Pinto, 2008).

$\mathrm{H}_{4}$ : Não há diferença significativa entre as respostas de pequenos empresários e vendedores.

$\mathrm{H}_{5}$ : Há diferença significativa da percepção entre os entrevistados com escolaridade de nível superior e os demais níveis (médio, fundamental, alfabetizados e analfabetos) (Almeida, 2007).

Considerando as hipóteses enumeradas, deu-se início a um estudo empírico partindo da percepção de que a análise consistente do tema proposto só pode ser procedida com base em dados primários. Os detalhes dos procedimentos e decisões do trabalho de campo estão apontados no trabalho.

Com o intuito de atingir os objetivos definidos, o trabalho possui mais quatro partes, além desta Introdução. A segunda parte traz uma discussão sobre os aspectos da Malandragem, fazendo suas distinções no tempo, bem como abordando suas facetas 
como o jeitinho. O próximo tópico tratará do método em si e dos procedimentos realizados para consecução da pesquisa, onde estes serão explicados e detalhados. Depois serão apresentadas as análises dos resultados, e por fim as considerações finais do estudo, com suas limitações, implicações e recomendações para futuras pesquisas.

\section{Malandragem}

A malandragem pode ser considerada como um sistema simbólico que por meio do campo da literatura, da música e das narrativas folclóricas, e dentro dessas narrativas encontra soluções parciais de uma contradição que ora se move num caso entre a ordem e a desordem, entre o trabalho e a vadiagem e por último, entre o indivíduo e a pessoa (Rocha, 2006). Segundo Borja, o malandro:

É aquele que consegue adaptar-se a diversas situações, que são flexíveis e dinâmicos e usa sua criatividade para buscar ideias inovadoras para situações difíceis. Todo brasileiro apresenta na sua personalidade traços diversos de malandragem, o que é necessário hoje em dia para a convivência em uma sociedade em que tudo pode ser resolvido com um jeitinho. (Borja ,2005, p. 5)

O jeitinho, traço marcante na sociedade brasileira, é uma forma pacífica de resolver alguns problemas utilizando simpatia, criatividade e as relações pessoais por meio da religião, pelo mesmo time de futebol, pelo gosto por determinado assunto. É uma saída intermediária para o impasse entre o pessoal e o impessoal (DaMatta, 1997).

O jeitinho tem sempre uma forma especial de solucionar os problemas, solução engenhosa. Tem por objetivo obter um resultado satisfatório para quem está utilizando- 
o, de forma que ambas as partes tenham harmonia (DaMatta, 1984). “O jeito é um modo pacífico e até mesmo legítimo de resolver tais problemas, provocando essa junção inteiramente casuística da lei com a pessoa que a está utilizando"' (Id., 1984, p. 66).

Diferentemente do jeitinho, o "sabe com quem está falando" tenta resolver a situação, mas de maneira conflituosa, recorrendo à hierarquização, lembrando ao outro que há sempre outra autoridade, ainda mais alta a quem ele possa recorrer (Id., 1984).

Graças ao jeitinho podem acontecer coisas boas ou más, pois se de um lado é uma forma que o brasileiro consegue sobreviver ganhando pouco dinheiro e muitas vezes sendo desrespeitado, o jeitinho também está na raiz de toda a corrupção da sociedade brasileira (Id., 1984).

O malandro seria o profissional do jeitinho e da arte de sobreviver nas situações difíceis. Ele usa expedientes e histórias para conseguir seu objetivo. Escolhe ficar em cima do muro, utilizando o pessoal e o impessoal (DaMatta, 1984).

O malandro brasileiro é uma figura muito simpática, como afirma Motta (2003). Ele até cita como exemplo que Walt Disney consagrou o malandro brasileiro na figura do Zé Carioca, o papagaio meio maluco, um típico malandro. A malandragem não usa de violência para obter o objetivo, usa uma forma elegante, utilizando de simpatia, sedução e de toda a sua astúcia para obter privilégios, usa forma pacífica ao invés de violência (Id., 1984). “Antes de ser um acidente ou mero aspecto da vida social brasileira, coisa sem consequência, a malandragem é um modo possível de ser. Algo muito sério, contendo suas regras, espaços e paradoxos..." (Id., p. 71,1984). A malandragem, juntamente com o jeitinho, é uma forma de tentar juntar a totalidade harmoniosa e concreta, razão esta de classificá-lo com valor social (DaMatta, 1984).

DaMatta (1997) gradua a malandragem socialmente aprovada como indo desde a esperteza e sagacidade, no sentido de agir com vivacidade para levar a vida, até a prática de atos desonestos, tornando muito tênue a linha que separa os dois extremos. 
Ainda, segundo DaMatta (1997) quando o malandro transforma a prática de viver sagazmente para viver de golpes, personifica então o bandido ou marginal.

DaMatta (1997) fala dos personagens do seu livro e diz que o malandro vive da contradição do sistema, ele não busca dominar o sistema de poder, diferentemente do herói. O autor afirma que o malandro surge dos carnavais, o herói das paradas, enquanto o renunciador sai das procissões, este rejeita todo o sistema criando seus próprios valores.

O malandro atua como uma pessoa que tem um modo de vida peculiar ao brasileiro, onde ele com meios idiossincráticos consegue através de sua astúcia e sua persuasão penetrar em várias esferas da sociedade, se beneficiando (DaMatta, 1997).

Sendo o comportamento da sociedade possivelmente explicável a partir dos ritos e seus atores como define DaMatta (1997), e sendo o malandro o protagonista do carnaval como rito, um desses atores, seria coerente transportá-lo para o ambiente empresarial, não somente com suas características principais, como também com as suas graduações.

O cenário empresarial brasileiro, se comparado à realidade de outros países desenvolvidos, convive com grandes dificuldades, como elevadas taxas de juros dificultando o acesso ao crédito, incidência de altos encargos sociais que desestimula a contratação de mão de obra, entre outras, e tornam desigual a competição entre as empresas nacionais e seus concorrentes internacionais.

Embora não servindo de justificativas para um comportamento criminoso por parte dos empresários brasileiros, essas dificuldades certamente indicam atalhos que seduzem alguns e os convidam para a prática de atos ilícitos e ilegais.

\section{Malandro de ontem e o malandro de hoje}


A malandragem à qual o trabalho se refere não é a malandragem presente nos anos 30 no Brasil, sobretudo no Rio de Janeiro, onde o malandro era confundido com bandido, marginal, mas sim o malandro pós-ditadura, aquele que segue uma regra moral usando o componente do humor para obter vantagens.

Muito embora não se tenha desenvolvido uma produção sociológica sobre a malandragem no contexto dos anos 30 , mesmo que o samba expressasse um conteúdo sociológico que denunciava os conflitos da política do Estado Novo (1937-1945), a objetificação da malandragem nos anos 70 evidencia um processo de 'domesticação científica' de um gênero discursivo.

O malandro vestido a caráter, com lenço no pescoço, navalha no bolso e chapéu de panamá, foi pouco a pouco substituído pelo não menos malandro 'jeitinho brasileiro', na forma de um conjunto de práticas sociais mais domesticadas e purificadas e, até certo ponto, livre das representações marginais e ameaçadas de violência e perigo, inscritas na malandragem carioca de 'antigamente' (Rocha, 2006, p. 117).

O malandro da década de 1930 estava associado à imagem de uma pessoa que se dava bem sem trabalhar e por isso aproveitava a vida. Vivia no universo da desordem, por isso muito próximo ao crime, enquanto o caxias trabalhava, vivia no universo da ordem e consequentemente não aproveitava a vida.

O malandro do Rio de Janeiro caracterizado na década de 1930 tem alguns elementos do papel do vagabundo de hoje, o dicionário Houaiss (2010) faz uma distinção entre o vagabundo e o malandro. Vagabundo significa vadio, desocupado e ocioso, enquanto que malandro é o indivíduo vivo, astuto. 
Segundo Rocha (2006), o caminho encontrado por setores intelectualizados simpatizantes da esquerda como forma de protesto silencioso à ditadura militar brasileira nos anos 1960 e 70 foi o culto à malandragem, tendo um significado político no cenário da época.

Por meio da malandragem, burlavam-se os mecanismos de censura, possibilitando comunicar de forma consentida as mensagens proibidas, contidas nas entrelinhas. Neste contexto, as diversas manifestações culturais da época da ditadura militar tinham notadamente significado político.

A figura do malandro foi bastante presente na época da ditadura militar no Brasil, conforme comenta Cristino:

[...] reconhecer sua riqueza para a história brasileira, na medida em que para esse tópico convergem tantos outros símbolos de nosso repertório, como o samba e a religiosidade de ascendência africana, além de se configurar num digno representante de uma geração de forte ação político-cultural. Contudo, também não seria uma feliz tarefa colocar esse emblema num lugar quase absoluto, como se fosse único na perspectiva de uma construção para todo um país. Indiscutivelmente, o personagem malandro entrelaça questões múltiplas e de modo muito peculiar. (Cristino, 2009, p. 41)

Rocha (2006) diz que é como se o malandro e a malandragem tivessem virado coisa do passado, hoje o resultado da visão do malandro é um discurso bem comportado, o qual não contém elementos de violência para dar lugar a enunciados da negociação e relativização. 


\section{O Malandro na Canção Popular Brasileira}

As artes populares são um indicativo dos valores vigentes na sociedade, nos vários momentos em que sejam focadas. Para este trabalho, entende-se que, particularmente, as letras de música popular que tratam da malandragem podem ser consideradas bons indicadores do que os termos "malandragem" e "malandro" representam, em várias épocas, para a sociedade brasileira.

Por isso, a seguir, são analisadas algumas das letras mais representativas no uso desses conceitos, desde a década de 1930 até os dias mais atuais.

\section{Lenço no pescoço (1932)}

Wilson Batista

Meu chapéu do lado / Tamanco arrastando / Lenço no pescoço / Navalha no bolso / Eu passo gingando / Provoco e desafio / Eu tenho orgulho / Em ser tão vadio / Sei que eles falam / Deste meu proceder / Eu vejo quem trabalha / Andar no miserê / Eu sou vadio / Porque tive inclinação / Eu me lembro, era criança / Tirava samba-canção / Comigo não / Eu quero ver quem tem razão / E eles tocam / E você canta /E eu não dou.

O malandro de Wilson Batista tem um jeito especial de vestir: chapéu de lado, tamanco (sapato de pobre), navalha no bolso, lenço no pescoço e orgulho de não ser tão vadio.

Portanto na visão dele o malandro é um sobrevivente da marginalidade e da pobreza. Na época, a canção provocou um embate com Noel Rosa que repondeu com a canção "Rapaz Folgado". 


\section{Rapaz Folgado (1933)}

Noel Rosa

Deixa de arrastar o teu tamanco / Pois tamanco nunca foi sandália / E tira do pescoço o lenço branco / Compra sapato e gravata / Joga fora esta navalha que te atrapalha / Com chapéu do lado deste rata / Da polícia quero que escapes / Fazendo um samba-canção / Já te dei papel e lápis / Arranja um amor e um violão / Malandro é palavra derrotista / Que só serve pra tirar / Todo o valor do sambista / Proponho ao povo civilizado / Não te chamar de malandro / E sim de rapaz folgado.

Na canção do Noel Rosa, ao sugerir a Wilson Batista largar a malandragem, ele recupera exatamente os mesmos predicados da malandragem que Wilson Batista havia descrito, mas o Noel Rosa tem uma visão negativa da malandragem ("malandro é palavra derrotista"). Resumindo: se Wilson Batista faz apologia da malandragem, Noel Rosa não.

\section{Malandro sofredor (1954)}

Ary Barroso

Quem vai a um samba em Mangueira / Chorando o fino a noite inteira / Chorando a noite inteira / Sabe que o malandro canta penando / Um amor que já foi seu / Mas tão depressa se perdeu / E é a mágoa dessa gente / Que sabe que essa vida não tem valor / E o samba traduz, na harmonia e na cadência / Malandro, sempre foi um triste sofredor / Quando a noite é de luar / Também vem pro terreiro / A lua lá no céu / 
Escutar o pandeiro / Há no samba uma tristeza / Que não posso cantar / É a própria natureza / Que quis dar ao malandro / A graça de entender / O que o samba quer dizer / Quem vai a um samba em Mangueira...

Traz a ideia de que o malandro também sofre por amor e busca se refugiar no samba, tema que sempre foi marcante na figura do malandro até os dias atuais. Para ele a malandragem está associada à canção, ao samba, ao violão, pois era a legislação da época.

\section{Malandro (1967)}

Jorge Aragão; Jotabê

Lá Laiá, Laiá Laiá, Laiá Laiá Laiá! / Laiá, Laiá, Laiá, Laiá Laiá! / Eh! Laiá, Laiá, Laiá Laiá Laiá! / Laiá Laiá Laiá, Laiá Laiá!... / Malandro! / Eu ando querendo / Falar com você / Você tá sabendo / Que o Zeca morreu / Por causa de brigas / Que teve com a lei / Malandro! / Eu sei que você / Nem se liga pro fato / De ser capoeira / Moleque mulato / Perdido no mundo / Morrendo de amor... / Malandro! / Sou eu que te falo / Em nome daquela / Que na passarela / É porta estandarte / E lá na favela / Tem nome de flôr... / Malandro! / Só peço favor / De que tenhas cuidado / As coisas não andam / Tão bem pro teu lado / Assim você mata / A Rosinha de dor... / Lá Laiá, Laiá Laiá, Laiá Laiá Laiá! / Laiá, Laiá, Laiá, Laiá Laiá! / Laiá, Laiá, Laiá Laiá Laiá! / Laiá Laiá Laiá, Laiá Laiá!... /Malandro!

O malandro, na canção de Jorge Aragão e Jatobê, é configurado ainda com os elementos da década de 30, sobretudo o malandro ligado ao Rio de Janeiro e ao samba, mas beirando a marginalidade. Ao mesmo tempo em que, de forma sutil, há mudança para 
uma pessoa que segue uma conduta moralmente mais aceita, no caso quando fala que ele está morrendo de amor, um sentimento nobre que lhe guia, é um malandro romântico no sentido individualista.

\section{O Malandro (1977) \\ Chico Buarque}

O malandrol Na dureza / Senta à mesal Do café / Bebe um golel De cachaça / Acha graçal E dá no pé / O garçom I No prejuízo / Sem sorriso I Sem freguês / De passagem I Pela caixa / Dá uma baixal No português / O galego I Acha estranho / Que o seu ganhol Tá um horror / Pega o lápis | Soma os canos / Passa os danos | Pro distribuidor / Mas o fretel Vê que ao todo / Há engodol Nos papéis / E pra cimal Do alambique / Dá um trambique | De cem mil réis / O usineiro I Nessa luta / Grita(ponte que partiu) / Não é idiota I Trunca a nota / Lesa o banco | Do Brasil / Nosso bancol Tá cotado / No mercadol Exterior / Então taxal A cachaça / A um preçol Assustador / Mas os ianques I Com seus tanques / Têm bem mais ol Que fazer / E proíbem I Os soldados / Aliados I De beber / A cachaçal Tá parada / Rejeitada I No barril / O alambique I Tem chilique / Contra o banco I Do Brasil / O usineiro I Faz barulho / Com orgulhol De produtor / Mas a sual Raiva cega / Descarregal No carregador / Este chegal Pro galego / Nega arregol Cobra mais / A cachaçal Tá de graça / Mas o fretel Como é que faz? / O galegol Tá apertado / Pro seu ladol Não tá bom / Então deixal Congelada / A mesada I Do garçom / O garçom vêl Um malandro / Sai 
gritandol Pega ladrão / E o malandrol Autuado / É julgado e condenado culpado / Pela situação.

Nesta canção, o malandro ainda tem sua imagem associada ao crime, mas acaba pagando por seus atos. $\mathrm{O}$ autor aproveita para fazer uma crítica social, registrando que, no final das contas, só o malandro, na base da pirâmide social, "é julgado e condenado culpado", revelando que sua sagacidade não é suficiente para torná-lo impune, como acontece com os demais personagens.

\section{Homenagem ao Malandro (1977)}

Chico Buarque

Eu fui fazer um samba em homenagem / à nata da malandragem, / que conheço de outros carnavais. / Eu fui à Lapa e perdi a viagem, / que aquela tal malandragem / não existe mais. / Agora já não é normal, / o que dá de malandro regular profissional, / malandro com o aparato de malandro oficial, / malandro candidato a malandro federal, / malandro com retrato na coluna social; / malandro com contrato, com gravata e capital, / que nunca se dá mal. / Mas o malandro para valer, não espalha, / aposentou a navalha, / tem mulher e filho e tralha e tal. / Dizem as más línguas que ele até trabalha, / mora lá longe e chacoalha num trem da Central.

Para Chico, existem duas castas de malandro, uma como na década de 30, só que este teve que buscar o trabalho para manter a família. A outra castra é a do malandro 
legitimado que se inseriu no espaço oficial e está moralmente amparado por um sistema de normas oficiais.

O velho malandro, oriundo das classes sociais mais baixas, já não tem espaço para viver de expedientes. Agora, ele virou operário, mora longe e precisa se deslocar nos precários meios de transporte coletivo, tem família e aposentou a navalha. Este instrumento, recorrentemente utilizado nas letras de canção sobre malandragem, funcionava como arma, manuseado com destreza mortal, sendo uma marca dos antigos malandros cariocas.

\section{A Volta do Malandro(1985)}

Chico Buarque

Eis o malandro na praça outra vez / Caminhando na ponta dos pés / Como quem pisa nos corações / Que rolaram nos cabarés / Entre deusas e bofetões / Entre dados e coronéis / Entre parangolés e patrões / O malandro anda assim de viés / Deixa balançar a maré / E a poeira assentar no chão / Deixa a praça virar um salão / Que o malandro é o barão da ralé.

Esta canção surge em resposta ao suposto desaparecimento do malandro, segundo Travancas:

Este personagem ressurge no seu ambiente "entre deusas e bofetões/ entre dados e coronéis/ entre parangolés e patrões" e com seus atos característicos "caminhando na ponta dos pés/ como quem pisa nos corações". É o malandro que Da Matta (1981:204) identifica em Pedro 
Malasartes. “E o malandro é um ser deslocado das regras formais da estrutura social, fatalmente excluído do mercado de trabalho, aliás definido por nós como totalmente avesso ao trabalho e altamente individualizado, seja pelo modo de andar, falar ou vestir-se". É possível visualizar o andar do malandro de Chico Buarque, assim como é possível associá-lo ao submundo dos jogos e cabarés. E ao afirmar que "o malandro é o barão da ralé" ele reúne aristocracia e marginalidade em um mesmo tipo social. Ralé significando a camada mais baixa da sociedade, a escória. (Travancas, 2003, pp. 9-10)

Continuando com Chico Buarque, o personagem do Malandro é ainda referido em outra canção:

\section{Desafio Do Malandro(1985)}

Chico Buarque

Você tá pensando que é da alta sociedade / Ou vai montar exposição de souvenir de gringo / Ou foi fazer a fé no bingo em chá de caridade / Eu não sei não, eu não sei não / Só sei que você vem com five o'clock, very well, my friend / A curriola leva um choque, nego não entende / E deita e rola e sai comentando / Que grande malandro é você / Você tá fazendo piada ou vai querer que eu chore? / A sua estampa eu já conheço do museu do império / Ou mausoléu de cemitério, ou feira de folclore / Eu não sei não, eu não sei não / Só sei que você vem com reco-reco, berimbau, farofa / A curriola tem um treco, nego faz galhofa / E deita e rola e sai comentando / Que grande malandro é você / Você que era um 
sujeito tipo jovial / Agora até mudou de nome / Você infelizmente continua igual / Fala bonito e passa fome / Vai ver que ainda vai virar trabalhador / Que horror / Trabalho a minha nega e morro de calor / Falta malandro se casar e ser avô / Você não sabe nem o que é o amor / Malandro infeliz / Amor igual ao seu, malandro tem quarenta e não diz / Respeite uma mulher que é boa e me sustenta/ Ela já foi aposentada / Ela me alisa e me alimenta / A bolsa dela tá furada / E a sua mãe tá na rua / Se você nunca teve mãe, eu não posso falar da sua / Eu não vou sujar a navalha nem sair no tapa / É mais sutil sumir da Lapa / Eu não jogo a toalha / Onde é que acaba essa batalha? / Em fundo de caçapa / Eu não sei não, eu não sei não / Só sei que você perde a compostura quando eu pego o taco / A curriola não segura, nego coça o saco / E deita e rola e sai comentando / Que grande malandro é você.

Nesta canção o malandro é desafiado, como em uma partida de sinuca em que o malandro aposta dinheiro. Neste contexto, o malandro tem sua imagem associada à boa vida e a não trabalhar e ser sustentado por uma mulher. O que lhe mantém é o atributo da boa conversa.

Por meio da conversa, ele consegue viver bem, preferindo não "sujar a navalha" no sangue do outro. Nota-se na canção a mudança no comportamento do malandro, de bandido para uma pessoa que quer viver bem sem cometer delitos. "É mais sutil sumir da Lapa", reduto tradicional da malandragem, no Rio de Janeiro.

\section{Malandragem (1985)}

Cazuza / Frejat 
Quem sabe eu ainda / Sou uma garotinha / Esperando o ônibus / Da escola, sozinha / Cansada com minhas / Meias três quartos / Rezando baixo / Pelos cantos / Por ser uma menina má / Quem sabe o príncipe / Virou um chato / Que vive dando / No meu saco / Quem sabe a vida / É não sonhar... / Eu só peço a Deus / Um pouco de malandragem / Pois sou criança / E não conheço a verdade / Eu sou poeta / E não aprendi a amar / Eu sou poeta / E não aprendi a amar... / Bobeira / É não viver a realidade / E eu ainda tenho / Uma tarde inteira / Eu ando nas ruas / Eu troco um cheque / Mudo uma planta de lugar / Dirijo meu carro / Tomo o meu pileque / E ainda tenho tempo / Prá cantar... / Eu só peço a Deus / Um pouco de malandragem / Pois sou criança / E não conheço a verdade / Eu sou poeta / E não aprendi a amar / Eu sou poeta / E não aprendi a amar...

Nesta canção, o termo malandragem muda de contexto, já que os autores pedem a Deus um pouco de malandragem, entendida aí no sentido mais de esperteza, de aprender a saber viver e descubrir a verdade da vida. Essa verdade, por sua vez, significando não ser enganado pelos outros, aprender mais sobre a vida e sair de suas ciladas. Apenas "um pouco de malandragem" já seria suficiente para isso. A malandragem como código de conduta que ajuda a sobreviver em meio à violência.

\section{Malandro Não Vacila(1998)}

Bezerra da Silva

Já falei pra você, que malandro não vacila / Já falei pra você, que malandro não vacila / Malandro não cai, nem escorrega / Malandro não 
dorme nem cochila / Malandro não carrega embrulho / E também não entra em fila / É mas um bom malandro / Ele tem hora pra falar gíria / Só fala verdade, não fala mentira / Você pode acreditar / Eu conheço uma pá de otário / Metido a malandro que anda gingando / Crente que tá abafando, e só aprendeu a falar:/Como é que é? Como é que tá?

A letra da canção retrata toda a astúcia do malandro, "malandro não vacila", "malandro não cai". No contexto da música o malandro segue uma regra moral, pois um bom malandro "só fala a verdade, não fala mentira", embora verdade e mentira inseridas na conduta moral do malandro não sejam, necessariamente, as mesmas para toda a sociedade.

\section{Malandro é Malandro, Mané é Mané (2000)}

Bezerra da Silva

E malandro é malandro / Mané é mané / Podes crer que é / Malandro é malandro / E mané é mané / Diz aí! / Podes crer que é... / Malandro é o cara / Que sabe das coisas / Malandro é aquele / Que sabe o que quer / Malandro é o cara / Que tá com dinheiro / E não se compara / Com um Zé Mané / Malandro de fato / É um cara maneiro / Que não se amarra / Em uma só mulher... / Já o Mané ele tem sua meta / Não pode ver nada / Que ele cagueta / Mané é um homem / Que moral não tem / Vai pro samba, paquera / E não ganha ninguém / Está sempre duro / É um cara azarado / E também puxa o saco / Prá sobreviver / Mané é um homem / Desconsiderado / E da vida ele tem / Muito que aprender... 
Nesta canção há certa inversão dos valores, antes o malandro era um cara "mau", vivia na desordem. Agora, o malandro "é de fato um cara maneiro", tem sorte, sendo bem aceito pela sociedade. E o seu opositor é o Mané, que no passado era o Caxias. Por mudança da figura do malandro, houve esse reposicionamento. $\mathrm{O}$ malandro segue sua regra moral e concilia com uma boa vida, continuando com traços marcantes de sua lábia, sua astúcia e esperteza. Em oposição, o Mané, por querer ser esperto à força, é um cara mal visto pela sociedade, "mané é um homem desconsiderado", "e da vida tem muito o que aprender".

\section{Malandro Demais Se Atrapalha (2005)}

Jangos

A humildade é uma dádiva de Deus / E gostaria que soubessem disso alguns amigos meus / Que vivem na cidade no caos e no inferno / E esquecem que ninguém é eterno / Mas ninguém aqui tem peito de aço, cumpádi / Esse é um dos ensinamentos da malandragem / A paz, o amor, a compreensão / Transparência e atitude no aperto de mão / Tem gente que foge da cruel realidade / E esquece que lá fora existe um mundo de verdade / Justificam falando dos problemas que tem / Mas problema por problema, velho, eu tenho também / Vivemos num mundo de classes sociais / Esquecemos que somos todos iguais. / Mas eu não vou fugir do foco da questão / Pra não dizerem que eu falo e nunca chego à conclusão. / Malandro demais se atrapalha / Maluco é mó vacilo é tu tentar alimentar fogo de palha / Malandro demais se atrapalha / Malandro que é malandro tá suave e nunca encosta na navalha / Malandro demais se atrapalha / Aí maluco eu digo que é 
melhor tu ir pegando as tuas tralhas/ Malandro demais se atrapalha / Malandro que é malandro sabe que não existe fita sem falha / Malandragem não é falar demais / Já disse o pensador: malandragem é sobreviver em paz. / Também não é falar de menos / É falar valorizando os princípios que nós temos / Humildade não é abaixar a cabeça / Nem se rebaixar por qualquer coisa que aconteça / Pensa rápido e fala devagar / Ninguém falou que é fácil, tu precisa acostumar / Malandragem é prestar atenção na conversa. / Malandragem é se ligar quando a atenção se dispersa / Malandragem é sentir quando um mané te atravessa / E humildemente retomar o assunto da conversa. / Éééééé, malandro demais se atrapalha Cão que late não morde / Não dá pra contar toda hora com a sorte / Você engana algumas pessoas de vez em quando / mas não engana todo mundo ao mesmo tempo / Já diz o velho brother Waldemar / Vamos devagar que eu to com pressa / Passando por aquilo que te estressa / Respeitando o próximo / Sem usar o outro de escada pra continuar a caminhada / Consciência limpa, livre leve e solto / Nada como um dia após o outro / Existe a justiça divina pra quem é gente fina / Vai pela sombra meu irmão / Não cospe pra cima que cai na cabeça / E aí... ouve o que eu te digo mas não espalha / Malandro demais se atrapalha.

A canção tenta recolocar o conceito de malandro para um malandro bom, quando fala que os ensinamentos da malandragem são "A paz, o amor, a compreensão" "Transparência e atitude no aperto de mão". Embora diga que malandro demais se atrapalha, com isso fica a evidência de que há resquicios do malandro enganador, seria quando o malandro ultrapassa a linha limite e se transforma em mané. Contudo ele 
alerta dizendo que "Malandragem é prestar atenção na conversa", "Malandragem é sentir quando um mané te atravessa" dando evidência de que a malandragem está mais para esperteza do que para a marginalidade.

\section{Malandragem (2006)}

Marcelo D2

Aí malandragem, é contigo mesmo, é contigo mesmo / Reza aquela lenda que malandragem não tem / Malandro que é malandro não fala pra ninguém / Antigamente era ceda, hoje a camisa é larga / A noite começa em qualquer lugar e acaba é na lapa / O que era calça branca agora virou bermudão / Mas continua o anel a pulseira e o cordão / Rolézinho a dois, de mustang 73 / O Hip-Hop com samba é Bola da vez / Rap brasileiro, viajou o mundo, se encheu de prêmio e agora / nobre vagabundo / Chega e tira onda, arrebenta as caixa / Entra lá na VIP e bebe cerveja na faixa / É isso que tu quer pra tua vida parceiro / Fumar um, tirar onda, e encher o bolso de dinheiro / Malandro que é malandro tem a cabeça feita / É a tal história da procura da batida perfeita / Ihhh, numa hora dessa e apita a consciência / Vários anos de barulho e tem que mostrar competência / Falar do que que eu fiz / É você fez sim / A consciência dói / Vc não vai se livrar de mim / Malandragem mesmo bebe duas e vaza / Leva respeito da rua e sempre o amor de casa / Mas que saber, essa eu fui esperto / Tenho amor e respeito / Eu to no caminho certo / Haha, O que? Só rimo com os bamba / Só nos beat boys / Só ando nos pano e represento os irmãos / Ihhh, lá vem você de novo com esse papo / É claro / O Mario ta na mesa e o primo nos pratos / 
Chega de mansinho, toma de assalto $\backslash \mathrm{O}$ bicho pega mesmo é lá em cima do palco / Olha aqui malandro não fica de blá-blá-blá / O papo é reto a fumaça que eu jogo pro ar / Um filme de malandragem sem querer tirar vantagem / Dedicação no jogo que o Rap é o som / Malandro que é malandro / Não fica de pinlantragem / O Rap é com samba então é o momento e fica bom / Papo cifrado só quem entende é a rua / O que aprendi na vida é que cada um cuida da sua / E esse sim, é malandro de verdade / Mantém a boca feixada com responsabilidade / Muda de conversa sem problema nenhum / Eu nunca vi e nem vou ver se neguinho fumar um / A conduta certa você sabe eu também / Ahãm / Código de rua que a malandragem sabe bem / Malandro isso / Malandro aquilo / Ve só quem fala / Se fosse um tempo atrás eu carregava é navalha / A vida ta boa, vai / Mas sem lamento / Agora que a gente ta se acertando no argumento / Então entramo num acordo eu e minha consciência / Eu vou no sapatinho e ela tem paciência / Conversa fiada / Cada um com a sua viagem / Apenas o roteiro de Um Filme Malandragem / Haha / Aí personagem / Tem que ouvir a sua conciência / A maior malandragem do mundo / É viver / É a maior malandragem do mundo / É viver / Então vai, vai, vai, vai.

A canção demonstra toda a mudança do conceito de malandro desde a década de 1930 até os dias atuais, e esbarra na ambiguidade do termo malandro, uma hora malandro que é malandro age "bem", outra hora malandro que é malandro age "mal", mas seguindo uma conduta moral típica do malandro e com sabedoria para viver bem. No fime, a letra termina dizendo que "a maior malandragem do mundo é viver", o que denota que com o tempo mudou o conceito de malandro, passando a ser socialmente 
mais aceito. Ou, ainda, que o malandro, de tão esperto, aprendeu que esperteza o transforma em mané e o atrapalha na consecução dos seus objetivos.

Tendo como base o corte histórico atual, no capítulo seguinte serão diferenciados os conceitos de esperto, malandro e trapaceiro, objetos de estudos da investigação.

\section{Metodologia}

A pesquisa é quantitativa, com base em ferramentas estatísticas, tentará encontrar correlações entre as ocorrências empíricas, que não são necessariamente relações de causa e efeito (Moreira, 2007).

Tem como proposta natureza descritiva, pois irá analisar a opinião de pequenos empresários e vendedores do varejo de pequeno porte com relação a atos ilícitos em consonância com a fundamentação do arcabouço teórico da pesquisa.

Inicialmente, irá discutir os tópicos e as definições abordadas na pesquisa, bem como as etapas exploratórias e descritivas, com a definição do instrumento de coleta e, por fim, os procedimentos estatísticos. Para o processo de construção do conhecimento desta pesquisa foi realizado, inicialmente, estudo exploratório, delineado por pesquisa bibliográfica sobre o conceito de Malandragem. Com referência em DaMatta (1997) subdivide-se o conceito de malandragem em cinco níveis de percepção Ética.

O primeiro nível mais brando denominou-se de Esperto, o segundo nível o intermediário denominou-se de Malandro, este por ser um termo ambíguo foi subdivido em três: pouco Malandro, Malandro e muito Malandro e o último nível o mais forte denominou-se de Trapaceiro. Com isso, as variáveis do instrumento de pesquisa indicam as percepções em diferentes situações.

\section{a) Esperto}

Brasiliana - Journal for Brazilian Studies. Vol. 2, n.2 (Nov 2013). ISSN 2245-4373. 
A esperteza é a capacidade que tem o indivíduo de encontrar-se em situações adversas, e conseguir reverter o cenário por meio de sua inteligência, de sua habilidade, tirando proveito da situação. Um sujeito esperto utiliza muito a criatividade. Segundo definição do dicionário Houaiss (2010) o esperto é um sujeito que não dorme e percebe tudo; atento, vigilante, vivo; inteligente, perspicaz, arguto, ladino; que age com rapidez e eficiência; ativo, enérgico, ligeiro. Em um sentido regional é um sujeito bacana. A definição abordada no trabalho de um sujeito esperto é aquele indivíduo inteligente, fino, arguto. Nada lhe escapa: é muito atento.

\section{b) Malandro}

A malandragem pode ser expressa como uma série de ações que o ator social executa para obter vantagem em determinadas situações, utilizando-se para isso de toda sua astúcia e sutileza para obter êxito, sendo obedecida uma regra moral pré-estabelecida, caracterizando-o como quase desonesto.O dicionário Houaiss (2010) define malandro como aquele que emprega recursos engenhosos para sobreviver. No sentido regional aquele que é sagaz, arguto, que se vale de astúcia enganosa; finório, espertalhão.

\section{c) Trapaceiro}

A trapaça é um ato em que o individuo através de maneira ilegal (crime) obtém vantagem. É uma ofensa que se utiliza de enganações e fraudes com o propósito de prejudicar os outros a fim de obter benefícios. O trapaceiro é um marginal em relação a lei. Segundo definição do dicionário Houaiss (2010), o trapaceiro é aquele que faz trapaças, faz ação ardilosa, de má-fé; fraude, logro. Tratar (algo), fraudulentamente 
como infringir o Código do Consumidor Brasileiro e/ou a Consolidação das Leis do Trabalho são exemplos de trapaça.

\section{Variáveis e construção do questionário}

A pesquisa de campo foi realizada a fim de obter parâmetros reflexivos que iluminassem os objetivos propostos pelo trabalho. Para tanto, foi construído um questionário, composto por questões que trataram de elucidar as proposições apontadas nas hipóteses.

A construção do instrumento de pesquisa foi elaborada anteriormente por (Pinheiro et. al., 2010). A escala do referido trabalho procedeu-se de duas etapas: a primeira foi uma sondagem inicial, através do levantamento teórico específico da área em livros e artigos. Em seguida, foi definida a estrutura do roteiro de pesquisa. $\mathrm{O}$ questionário foi dividido em dois blocos: no primeiro bloco foram contemplados dados demográficos e sócio-econômicos, o segundo bloco foi constituído pela análise de nove variáveis nas quais o respondentes podiam marcar determinada situação como esperteza malandragem ou trapaça.

A segunda etapa foi a validação do conteúdo do roteiro. $O$ instrumento foi submetido a três professores estudiosos da área e foram feitas correções quanto ao posicionamento e direcionamento das questões e melhorias em termos de linguagem.

No questionário ora aplicado, foram feitos os mesmos procedimentos iniciais, com alterações no número de situações de trapaças que passa de nove para dezoito, bem como nos quesitos de respostas, onde houve um aumento da categoria malandragem de uma para três, ficando: esperto, pouco malandro, malandro, muito malandro e trapaceiro, também dividida em dois blocos,o primeiro bloco com as dezoito situações e o segundo bloco contemplou os dados demográficos e socioeconômicos.

Brasiliana - Journal for Brazilian Studies. Vol. 2, n.2 (Nov 2013). ISSN 2245-4373. 
O questionário foi dividido com questões que continham práticas que lesam o governo (questões 13, 14 e 15) e práticas que lesam a pessoa (cliente e o trabalhador) (questões 1, 2, 3, 4, 5, 6, 7, 8, 9, 10, 11, 12, 16, 17 e 18) para melhor verificar as percepções dos pequenos empresários e vendedores.

A fim de esclarecer cada questão, procura-se justificar cada item proposto, o que está sintetizado no Quadro 1.

\begin{tabular}{l|}
\hline \multicolumn{1}{c|}{ Questão } \\
\hline Questão 1: “Empurrar um produto” aos \\
clientes para atingir metas \\
\hline Questão 2: Se negar a trocar uma \\
mercadoria dentro dos prazos previsto \\
no Código do Consumidor
\end{tabular}

Questão 3: Fazer uma venda casada Fundamentação Fere o art. 39, inciso IV do código de defesa do consumidor (CDC) (lei 8.078/90). Fere o art. 18, nos parágrafos $\S 1^{\circ}$, I, $\S 2^{\circ}$, $\S 3^{\circ}$ e $\S 4^{\circ}$ do CDC, onde o fornecedor tem a responsabilidade por vício do produto e do serviço.

Constitui uma infração contra a ordem econômica ferindo o art. 39, inciso I do CDC e crime contra a economia e as relações de consumo, ferindo o art. $5^{\circ}$, inciso II da lei $8.137 / 90$.

Questão 4: Entregar um produto similar ou substituto em vez do originalmente comprado Isto constitui ato de infração de práticas comerciais da Questão 5: Prometer entregar uma mercadoria num prazo menor mesmo sabendo que não será cumprido Questão 6: Deixar de entregar ao consumidor o termo de garantia adequadamente preenchido e com especificação clara de seu conteúdo oferta e da publicidade, os artigos $30,31,37$, § $1^{\circ}$, do CDC.

Questão 7: Não assinar a carteira de trabalho do empregado Ato que fere, além dos artigos descritos na questão anterior (artigos 30, 31, 37, § 1ํㅡㄹ do CDC), o art. 35, inciso I.

Questão 8: Registrar em carteira um salário menor do que aquele efetivamente pago

Questão 9: Comprar os trinta dias de férias do trabalhador

Isto é uma infração que é respalda conforme o art. 50, parágrafo único e o art. 74 do $C D C$, onde o empresário é obrigado a entregar o termo de garantia com as devidas especificações tendo pena de detenção ou multa. Fere a Consolidação das Leis Trabalhistas (decreto lei 5.452 de 1943) nos artigos 13 e 29 , § 3.

Também fere a Consolidação das Leis Trabalhistas no art. $29, \S 1$.

Questão 10: Não Devolver o dinheiro quando ocorre erro no produto

Questão 11: Não informar corretamente as taxas de juros incluindo todos os

Ainda com relação à Consolidação das Leis Trabalhistas, este ato fere o art. 143, parágrafo único, pois o empregador só pode comprar no máximo $1 / 3$ do período de férias.

$\mathrm{O}$ ato fere o CDC quando este se refere à responsabilidade por vício do produto e do serviço por parte do fornecedor, é respaldado no art. 18, $\S 1^{\circ}$, inciso II do CDC.

A ação fere o CDC, em suas cláusulas abusivas, no art. 52, incisos I, II, III, IV e V. 


\begin{tabular}{|c|c|}
\hline $\begin{array}{l}\text { custos de crédito da operação, como por } \\
\text { exemplo, IOF }\end{array}$ & \\
\hline $\begin{array}{l}\text { Questão 12: Cobrar a Taxa de Abertura } \\
\text { de Crédito }\end{array}$ & $\begin{array}{l}\mathrm{O} \text { ato fere o } \mathrm{CDC} \text {, no art. } 39 \text {, inciso } \mathrm{V} \text { e } \mathrm{X} \text {, quando este } \\
\text { aborda práticas abusivas. }\end{array}$ \\
\hline $\begin{array}{l}\text { Questão 13: Vender mercadorias sem } \\
\text { notas ou meia nota }\end{array}$ & $\begin{array}{l}\text { Constitui crime contra a ordem tributária, no art. } 1^{\circ} \text {, inciso } \\
\text { II e V da lei } 8.137 / 90 \text {. Também o art. 127, incisos I, II e III } \\
\text { do Decreto } 24.569 \text { do Regulamento do ICMS do Estado do } \\
\text { Ceará (RICMS) relata a ação descrita. }\end{array}$ \\
\hline $\begin{array}{l}\text { Questão 14: Não emitir todas as notas } \\
\text { fiscais de venda }\end{array}$ & $\begin{array}{l}\text { Seguindo a mesma linha, repete-se a justificativa do item } \\
\text { anterior, que também constitui crime contra a ordem } \\
\text { tributária, pode ser conferida no art. } 1^{\circ} \text {, incisos II e V da lei } \\
8.137 / 90 \text {. }\end{array}$ \\
\hline Questão 15: Manter caixa 2 & $\begin{array}{l}\text { Este crime também constitui contra a ordem tributária, } \\
\text { respaldada no art. } 1^{\circ} \text {, incisos I, II e V e no art. } 2^{\circ} \text {, inciso I da } \\
\text { lei } 8.137 / 90 .\end{array}$ \\
\hline $\begin{array}{l}\text { Questão 16: Comprar mercadorias } \\
\text { quase vencidas para fazer promoções }\end{array}$ & $\begin{array}{l}\text { Afeta um direito básico do consumidor, bem como o uso } \\
\text { de publicidade abusiva, a questão é respaldada no art. } 6 \text {, } \\
\text { inciso VI e no art. } 37, \S 3^{\circ} \text { do CDC. }\end{array}$ \\
\hline $\begin{array}{l}\text { Questão 17: Colocar produtos } \\
\text { danificados na promoção sem informar } \\
\text { ao cliente }\end{array}$ & $\begin{array}{l}\text { Este ato também vai afetar o direito básico do consumidor, } \\
\text { bem como o uso de publicidade abusiva, o art. } 6 \text {, inciso III } \\
\text { e IV e o art. } 37, \S 3^{\circ} \text { do CDC. }\end{array}$ \\
\hline $\begin{array}{l}\text { Questão 18: Nas promoções não } \\
\text { informar os juros de mora e a taxa } \\
\text { efetiva anual de juros }\end{array}$ & $\begin{array}{l}\text { Constitui uma infração contida nas cláusulas abusivas do } \\
\text { CDC, mas precisamente no art. 52, inciso II. }\end{array}$ \\
\hline
\end{tabular}

Quadro 1. Construção do questionário

\section{Descrição da parte empírica}

O campo da pesquisa foi composto por micro e pequenas empresas de comércio varejista da Região Metropolitana de Fortaleza (RMF) e da Região Metropolitana do Cariri (RMC), ambas no estado do Ceará.

Os sujeitos da amostra são pequenos empresários e vendedores do comércio varejista. Dada a indefinição do tamanho exato do universo da pesquisa e a dificuldade na abordagem junto aos pequenos empresários e vendedores procedeu-se a uma amostragem por conveniência.

Ressalta-se a importante preocupação do estudo com a amostra mínima necessária para a utilização da técnica de análise estatística, no caso a análise fatorial, 
primeira a ser utilizada, que exige de acordo com Corrar et. al. (2007), pelo menos cinco vezes mais observações que a quantidade de variáveis a serem analisadas. Considerando que foram avaliadas dezoito variáveis, a quantidade de questionários aplicados supera em muito a quantidade mínima orientada pelo autor citado.

\section{Procedimentos de Análise Estatística}

Os procedimentos utilizados foram de análise descritiva e de análise multivariada. Todos os procedimentos estatísticos foram realizados conforme orientação de literatura especializada (Field, 2009; Corrar et. al., 2007; Malhotra, 2006)4.

A técnica de análise foi a estatística descritiva com a construção de distribuições de freqüências das variáveis pesquisadas. Depois, se procedeu à técnica de Análise Fatorial Exploratória. A Análise Fatorial busca, através de um conjunto de variáveis, a identificação de dimensões de variabilidade comuns existentes em um conjunto de fenômenos. Ela identifica fatores que podem ser usados para explicar o relacionamento entre um conjunto de variáveis (Corrar et. al., 2007).

$\mathrm{Na}$ aplicação da Análise Fatorial, o método de extração dos fatores utilizado foi "Componente Principal" com rotação "Varimax". Os testes selecionados foram: KMO, Bartlett's test of sphericity, Matriz antiimagem e comunalidade. Foi aplicada, antes da Análise Fatorial, a análise de confiabilidade dos dados definida como "Alfa de Cronbach".

Depois, para verificar as diferenças de percepções de pequenos empresários e vendedores, das regiões e do nível de escolaridade dos respondentes, foi aplicada a

\footnotetext{
${ }^{4}$ Os procedimentos estatísticos foram realizados por meio do software SPSS, versão 15 e com o apoio do software Microsoft Excell, versão 2007.
}

Brasiliana - Journal for Brazilian Studies. Vol. 2, n.2 (Nov 2013). ISSN 2245-4373. 
técnica de Análise de Variância (ANOVA). Feito o método da pesquisa, o próximo passo será apresentar os resultados encontrados na investigação.

\section{Aplicação e Análise dos Dados}

Depois da tabulação dos dados foi feita inicialmente uma análise exploratória preliminar dos dados e não foi achado nenhum missing value relacionado às variáveis do estudo, pois o pesquisador teve a preocupação de na hora da coleta não deixar nenhum espaço em branco. Só houve dado faltante com relação à renda mensal e sobre a idade. Foram coletados 221 questionários, aplicados no mês de maio de 2010.

\section{Descrição da Amostra}

Os dados da descrição da amostra estão classificados em dois grupos. O primeiro referese aos dados demográficos e socioeconômicos, especificamente sexo, estado civil, idade, renda e escolaridade. $\mathrm{O}$ segundo grupo refere-se a questões sobre o segmento de atuação e o tipo de respondente se empresário ou vendedor.

\section{Informações demográficas}

Dos 221 respondentes, 138 são do sexo feminino, representando 62\% da amostra, enquanto 83 são do sexo masculino, o que representa $38 \%$ da amostra. O cruzamento com a região indicou que as mulheres são maioria na RMC e que na RMF a quantidade de homens e mulheres foi exatamente igual. Em relação ao tipo de respondente, verificou-se que as mulheres são maioria entre os vendedores, ao passo que os homens são maioria no empresariado.

Brasiliana - Journal for Brazilian Studies. Vol. 2, n.2 (Nov 2013). ISSN 2245-4373. 
Com relação ao estado civil, a maioria informou ser casada, com $52 \%$ do total dos respondentes, enquanto $42 \%$ declararam serem solteiros, e $6 \%$ apontaram 'outros' como resposta. Este resultado está em consonância com a idade, ou seja, normalmente este público está em fase adulta em fase de consolidação profissional.

Quanto à idade, a maioria se concentra na faixa que vai de 20 a 30 anos (42\%), logo em seguida vem um número significante de respondentes na faixa entre 30 até 40 anos (20\%) e acima de 40 até 50 anos (18\%), se somadas estas três faixas têm-se um total de $80 \%$ inseridos entre acima de 20 a 50 anos. O público jovem em sua maioria está concentrado entre os vendedores, em que mais de $70 \%$ destes estão com idade até 30 anos.

Em relação à renda mensal dos respondentes. Os resultados demonstram que a grande maioria percebe até $\mathrm{R} \$ 2.000,00(73 \%)$, caracterizando assim um setor de pequeno porte. Os que percebem acima de $\mathrm{R} \$ 2.000,00$ até $\mathrm{R} \$ 3.000,00$ também estão bem representados com $15 \%$ da amostra. Os que ganham acima de $\mathrm{R} \$ 4.000,00$ representa apenas $11 \%$ da amostra. Um ponto a ressaltar é que $92 \%$ dos vendedores auferem renda até $R \$ 2.000,00$. Quanto à escolaridade, a grande maioria possui o ensino médio completo (60\%); percebe-se também que um bom número está cursando o nível superior (16\%); com nível superior completo a parcela é pequena $(13 \%)$.

\section{Informações associado ao segmento}

Sobre o tipo de pessoa, foi preocupação da investigação, contrair percentuais próximos, com isso a amostra foi composta por 110 empresários e 111 vendedores. Com relação à região do negócio também seguiu o mesmo procedimento, com proporção de cerca de $50 \%$ para cada região e $50 \%$ por tipo de pessoa.

Brasiliana - Journal for Brazilian Studies. Vol. 2, n.2 (Nov 2013). ISSN 2245-4373. 
Quanto ao segmento de atuação, nota-se uma grande diversidade, já que foram identificados 22 segmentos de varejo de pequeno porte. Destaca-se o segmento de confecção com 35\% da amostra e o segmento dos mercadinhos com 12\%, outro segmento representativo foi o de presentes e variedades com $8 \%$.

\section{Distribuição de Frequências}

A distribuição de frequência foi aplicada no intuito de observar a percepção dos respondentes com relação à trapaça. Aplicou-se aos dados a distribuição de frequência, conforme é possível verificar na TAB. 1.

De acordo com a TAB. 1 foi verificado que a hipótese $\mathrm{H}_{1}$ : Malandragem é um traço da cultura e da moral brasileira, portanto, maior parte das respostas está concentrada na opção malandragem' foi refutada, pois a maior parte das respostas ficou concentrada no item trapaceiro.

Tabela 1:

Percepção dos respondentes sobre as dimensões do estudo

\begin{tabular}{|c|c|c|c|c|c|}
\hline \multirow{2}{*}{ Variáveis } & \multicolumn{5}{|c|}{ Dimensões } \\
\hline & $\mathrm{E}$ & PM & $\mathrm{M}$ & $\mathrm{MM}$ & $\mathrm{T}$ \\
\hline "Empurrar um produto" aos clientes para atingir metas & $34 \%$ & $10 \%$ & $24 \%$ & $8 \%$ & $24 \%$ \\
\hline $\begin{array}{l}\text { Se negar a trocar uma mercadoria dentro dos prazos } \\
\text { previstos no Código do Consumidor }\end{array}$ & $12 \%$ & $4 \%$ & $18 \%$ & $11 \%$ & $55 \%$ \\
\hline Fazer uma venda casada & $50 \%$ & $2 \%$ & $16 \%$ & $6 \%$ & $26 \%$ \\
\hline $\begin{array}{l}\text { Entregar um produto similar ou substituto em vez do } \\
\text { originalmente comprado }\end{array}$ & $8 \%$ & $5 \%$ & $18 \%$ & $18 \%$ & $51 \%$ \\
\hline $\begin{array}{l}\text { Prometer entregar uma mercadoria num prazo menor } \\
\text { mesmo sabendo que não será cumprido }\end{array}$ & $8 \%$ & $7 \%$ & $30 \%$ & $15 \%$ & $40 \%$ \\
\hline $\begin{array}{l}\text { Deixar de entregar ao consumidor o termo de garantia } \\
\text { adequadamente preenchido e com especificação clara de seu } \\
\text { conteúdo }\end{array}$ & $13 \%$ & $5 \%$ & $26 \%$ & $9 \%$ & $47 \%$ \\
\hline Não assinar a carteira de trabalho do empregado & $21 \%$ & $5 \%$ & $15 \%$ & $11 \%$ & $48 \%$ \\
\hline $\begin{array}{l}\text { Registrar em carteira um salário menor do que aquele } \\
\text { efetivamente pago }\end{array}$ & $20 \%$ & $5 \%$ & $18 \%$ & $14 \%$ & $43 \%$ \\
\hline
\end{tabular}

Brasiliana - Journal for Brazilian Studies. Vol. 2, n.2 (Nov 2013). ISSN 2245-4373. 


\begin{tabular}{|c|c|c|c|c|c|}
\hline Comprar os trinta dias de férias do trabalhador & $57 \%$ & $6 \%$ & $16 \%$ & $5 \%$ & $16 \%$ \\
\hline Não Devolver o dinheiro quando ocorre erro no produto & $12 \%$ & $3 \%$ & $19 \%$ & $18 \%$ & $48 \%$ \\
\hline $\begin{array}{l}\text { Não informar corretamente as taxas de juros incluindo todos } \\
\text { os custos de crédito da operação, como por exemplo, IOF }\end{array}$ & $14 \%$ & $5 \%$ & $24 \%$ & $16 \%$ & $41 \%$ \\
\hline Cobrar a Taxa de Abertura de Crédito & $28 \%$ & $4 \%$ & $19 \%$ & $16 \%$ & $33 \%$ \\
\hline Vender mercadorias sem notas ou meia nota & $22 \%$ & $5 \%$ & $26 \%$ & $10 \%$ & $37 \%$ \\
\hline Não emitir todas as notas fiscais de venda & $26 \%$ & $6 \%$ & $22 \%$ & $10 \%$ & $36 \%$ \\
\hline Manter caixa 2 & $13 \%$ & $2 \%$ & $15 \%$ & $11 \%$ & $59 \%$ \\
\hline Comprar mercadorias quase vencidas para fazer promoções & $17 \%$ & $1 \%$ & $19 \%$ & $19 \%$ & $44 \%$ \\
\hline $\begin{array}{l}\text { Colocar produtos danificados na promoção sem informar ao } \\
\text { cliente }\end{array}$ & $5 \%$ & $1 \%$ & $14 \%$ & $19 \%$ & $61 \%$ \\
\hline $\begin{array}{l}\text { Nas promoções não informar os juros de mora e a taxa } \\
\text { efetiva anual de juros }\end{array}$ & $16 \%$ & $5 \%$ & $23 \%$ & $21 \%$ & $35 \%$ \\
\hline
\end{tabular}

Fonte: Dados da pesquisa.

Para verificar a hipótese $\mathrm{H}_{2}$ que afirma que 'Empresário e vendedor tendem a reconhecer a trapaça quando ela prejudica uma pessoa (trabalhador e cliente) e não tem a mesma clareza moral quando ela prejudica a coletividade (Pinheiro et al.,2010)' foi verificado nas questões pertinentes as práticas que lesam o cliente e o trabalhador e as que lesam o governo, os maiores índices se concentram na dimensão trapaceiro, refutando a hipótese.

\section{Resultados da aplicação da Análise Fatorial}

A análise fatorial procedeu-se junto às variáveis da pesquisa, como forma de avaliar preliminarmente a estrutura fatorial destas em relação aos aspectos definidos, além de viabilizar uma maior consistência na análise dos modelos de mensuração.

A análise fatorial, busca na investigação, a redução da quantidade de variáveis originais para propiciar uma melhor interpretação das relações entre as variáveis definidas na pesquisa. As denominações dos fatores foram feitas com a preocupação de fazer sentido com a teoria de suporte do trabalho.

Brasiliana - Journal for Brazilian Studies. Vol. 2, n.2 (Nov 2013). ISSN 2245-4373. 
Com isto, realizou-se inicialmente uma explanação dos dados, além da análise de confiabilidade dos dados com o coeficiente alpha de Cronbach, que foi extraído junto aos itens da escala.

\section{Confiabilidade}

Com relação à análise de confiabilidade dos itens dos construtos foi utilizado o índice alpha de Cronbach, modelo de consistência interna baseada na correlação média entre os itens (Corrar et. al., 2007). O índice varia de zero a um, e a literatura especializada aponta que valores até 0,6 indicam inconsistência na escala, valores entre 0,6 e 0,8 indicam confiabilidade razoável, e valores acima de 0,8 indicam confiabilidade muito alta (Malhotra, 2006). O alpha de Cronbach da pesquisa foi 0,822, podendo inferir que a escala tem confiabilidade muito alta e demonstra que é consistente, sendo satisfatória para aplicação da análise multivariada.

\section{Análise Fatorial}

$\mathrm{Na}$ aplicação da Análise Fatorial consideraram-se inicialmente todas as variáveis envolvidas no estudo. O método de extração dos fatores utilizado foi "Componente Principal" com rotação "Varimax". Os testes selecionados foram: KMO, Bartlett's test of sphericity e Matriz antiimagem.

Na presente pesquisa, observa-se que o teste de esfericidade de Bartlett indicou um alto poder de explicação entre fatores e as variáveis $(\mathrm{KMO}=0,836$; Barttlet' $\mathrm{s}=832,883$; sig.=0,000). Para que seja possível a aplicação, recomenda-se o valor de sig. (teste de significância) não ultrapasse 0,05 . O teste indicou a possibilidade de aplicação da análise fatorial nas variáveis analisadas.

Brasiliana - Journal for Brazilian Studies. Vol. 2, n.2 (Nov 2013). ISSN 2245-4373. 
A opção Antiimagem carrega na sua diagonal o valor do Measure of Sampling Adequacy (MAS) para cada uma das variáveis e nos demais campos mostra a correlação parcial. Uma boa análise fatorial possui valores, não considerando a diagonal da matriz, muito pequenos na correlação parcial. Os valores da diagonal principal, assinalados com a letra "a" inferiores a 0,5 são considerados muito pequenos para análise e nesse caso indicam variáveis que podem ser retiradas da análise. No entanto, não existiram variáveis prejudicando o resultado, apresentando para cada indicador valores superiores a 0,5 . O menor valor encontrado foi 0,76. Sendo assim, prosseguiu-se com as análises.

Além do bom índice do $\mathrm{KMO}$, todas as variáveis possuem um satisfatório poder de explicação. Outra análise que pode ser feita é o grau de explicação atingindo pelas 18 variáveis. O modelo consegue explicar por meio de 6 componentes cerca de $60 \%$ da variância total dos dados.

- Fator 1 - Crimes fiscais contra governo e trabalhador: Este fator refere-se às questões relacionadas com penalidades que são aplicadas pelas autoridades tributárias, nas quais a variável 'Vender mercadorias sem notas ou meia nota' e 'Não assinar a carteira de trabalho do empregado' são as variáveis que mais explicam esse fator. As outras variáveis: ‘Não emitir todas as notas fiscais de venda' e 'Registrar em carteira um salário menor do que aquele efetivamente pago' também compõe o fator. Analisando a TAB. 7 nota-se que nas questões que afetam o empregado há um reconhecimento maior da trapaça, já quando afeta o governo, embora os maiores índices estejam na trapaça, há uma queda neste reconhecido, o que indica uma relativização das práticas ilegais contra o governo. No trabalho de Pinheiro et. al.(2010) também houve indícios de relativização das práticas ilegais. 
- Fator 2 - Comportamento abusivo em promoção: $\mathrm{O}$ segundo fator refere-se às práticas abusivas nas promoções. A variável que mais explica este fator é 'Colocar produtos danificados na promoção sem informar ao cliente', como também a que teve maior reconhecimento da trapaça, conforme TAB. 7. Para as variáveis 'Comprar mercadorias quase vencidas para fazer promoções' e 'Nas promoções não informar os juros de mora e a taxa efetiva anual de juros' houve reconhecimento da trapaça, embora com índices bem menores.

- Fator 3 - Comportamento abusivo em relação ao produto: Este fator, diz respeito às práticas abusivas com os produtos, 'Se negar a trocar uma mercadoria dentro dos prazos previstos no Código do Consumidor' é a variável que mais explica o fator. 'Prometer entregar uma mercadoria num prazo menor mesmo sabendo que não será cumprido', ‘Deixar de entregar ao consumidor o termo de garantia adequadamente preenchido e com especificação clara de seu conteúdo' e 'Entregar um produto similar ou substituto em vez do originalmente comprado' são as outras variáveis que compõe o fator. Observa-se que neste fator há um grande reconhecimento da trapaça. A exceção fica por conta da variável 'Prometer entregar uma mercadoria num prazo menor mesmo sabendo que não será cumprido' que deu o menor índice de reconhecimento da trapaça entre as variáveis do fator, interessante notar que esta foi a variável que de toda a escala teve o maior índice concentrado na dimensão malandro com 30\% dos respondentes.

Tabela 2:

Matriz dos componentes

\begin{tabular}{|l|c|c|c|c|c|c|}
\hline \multicolumn{1}{|c|}{ Variáveis } & \multicolumn{5}{c|}{ Fatores } \\
\cline { 2 - 6 } & 1 & 2 & 3 & 4 & 5 & 6 \\
\hline $\begin{array}{l}\text { "Empurrar um produto" aos clientes para } \\
\text { atingir metas }\end{array}$ & & & & & & 0,685 \\
\hline $\begin{array}{l}\text { Se negar a trocar uma mercadoria dentro dos } \\
\text { prazos previstos no Código do Consumidor }\end{array}$ & & & 0,727 & & & \\
\hline
\end{tabular}

Brasiliana - Journal for Brazilian Studies. Vol. 2, n.2 (Nov 2013). ISSN 2245-4373. 
Lôbo, Rodolfo Jakov Saraiva; Pinheiro, Daniel Rodriguez de Carvalho. Espertos ou Malandros: Como Pequenos Empresários e Vendedores Justificam Práticas Lesivas.

\begin{tabular}{|c|c|c|c|c|c|c|}
\hline Fazer uma venda casada & & & & 0,505 & & \\
\hline $\begin{array}{l}\text { Entregar um produto similar ou substituto } \\
\text { em vez do originalmente comprado }\end{array}$ & & & 0,548 & & & \\
\hline $\begin{array}{l}\text { Prometer entregar uma mercadoria num } \\
\text { prazo menor mesmo sabendo que não será } \\
\text { cumprido }\end{array}$ & & & 0,673 & & & \\
\hline $\begin{array}{l}\text { Deixar de entregar ao consumidor o termo } \\
\text { de garantia adequadamente preenchido e } \\
\text { com especificação clara de seu conteúdo }\end{array}$ & & & 0,648 & & & \\
\hline $\begin{array}{l}\text { Não assinar a carteira de trabalho do } \\
\text { empregado }\end{array}$ & 0,743 & & & & & \\
\hline $\begin{array}{l}\text { Registrar em carteira um salário menor do } \\
\text { que aquele efetivamente pago }\end{array}$ & 0,678 & & & & & \\
\hline $\begin{array}{l}\text { Comprar os trinta dias de férias do } \\
\text { trabalhador }\end{array}$ & & & & 0,759 & & \\
\hline $\begin{array}{l}\text { Não Devolver o dinheiro quando ocorre erro } \\
\text { no produto }\end{array}$ & & & & & 0,347 & \\
\hline $\begin{array}{l}\text { Não informar corretamente as taxas de juros } \\
\text { incluindo todos os custos de crédito da } \\
\text { operação, como por exemplo, IOF }\end{array}$ & & & & 0,518 & & \\
\hline Cobrar a Taxa de Abertura de Crédito & & & & 0,538 & & \\
\hline Vender mercadorias sem notas ou meia nota & 0,746 & & & & & \\
\hline Não emitir todas as notas fiscais de venda & 0,711 & & & & & \\
\hline Manter caixa 2 & & & & & 0,754 & \\
\hline $\begin{array}{l}\text { Comprar mercadorias quase vencidas para } \\
\text { fazer promoções }\end{array}$ & & 0,696 & & & & \\
\hline $\begin{array}{l}\text { Colocar produtos danificados na promoção } \\
\text { sem informar ao cliente }\end{array}$ & & 0,690 & & & & \\
\hline $\begin{array}{l}\text { Nas promoções não informar os juros de } \\
\text { mora e a taxa efetiva anual de juros }\end{array}$ & & 0,611 & & & & \\
\hline
\end{tabular}

Fonte: Dados da pesquisa.

- Fator 4 - Venda de um produto bom, casado com um produto ruim: Este fator fere várias práticas ilegais. A variável 'Comprar os trinta dias de férias do trabalhador' é a que mais explica o fator e, analisando a TAB. 7, esta variável teve um alto índice de definição na dimensão esperto com 57\% dos respondentes. A variável ‘Fazer uma venda casada' também teve um alto índice de definição como esperto, as outras variáveis relacionadas às práticas financeiras tiveram reconhecimento da trapaça, embora com 
baixos índices, tanto que na variável 'Cobrar a taxa de abertura de crédito' o índice de esperto ficou muito próximo do percentual da dimensão trapaceiro.

- Fator 5 - Apropriação indevida: Este fator é composto por duas variáveis. A que mais explica o fator é 'manter caixa 2'. A outra variável, 'Não devolver o dinheiro quando ocorre erro no produto' tem baixo poder de explicação do fator. Analisando a TAB. 7 nota-se que nas duas variáveis, os respondentes tendem a expressar um alto reconhecimento da trapaça.

- Fator 6 - Empurrar um produto: Este fator é composto apenas por uma variável denominada pelo mesmo nome do fator. Tem um bom poder de explicação, com relação aos respondentes nota-se que a maioria considera que quem faz esta prática é tido como esperto. No estudo de Pinheiro et. al.(2010) esta variável também foi definida como esperto, inclusive com um índice ainda maior.

\section{Resultados da aplicação da Análise de Variância Simples (ANOVA)}

Visando a verificar a hipótese 'H3: Não há diferença significativa entre as respostas da RMF e da RMC sobre as práticas lesivas recorrentes (trapaças), portanto, não há nesse caso, influência da cultura regional (Pinto, 2008)' foi realizada a análise de variância entre as regiões pesquisadas.

Inicialmente, foi feito o teste de homogeneidade (teste de Levene), este teste verifica se as variâncias dos grupos são significativamente diferentes, "se o teste de Levene é significativo (isto é o valor do Sig é menor do que 0,05), podemos dizer que as variâncias são significativamente diferentes" (Field, p.331, 2009). Na presente situação a 
análise de variância entre a RMF e RMC e todos os índices acima deste valor, o que indica que pode-se continuar com a ANOVA.

No julgamento dos resultados, com os dados segmentados por região, verificouse que o fator 4 (Venda de um produto bom, casado com um produto ruim) e o fator 6 (Empurrar um produto) encontraram diferenças significativas entre as opiniões dos respondentes da RMF e da RMC.

Analisando o fator 'venda de um produto bom, casado com um ruim' por região, nota-se que a RMC tende a reconhecer mais a trapaça que a RMF.

Este resultado pode trazer indícios de que os empresários e vendedores da RMC reconhecem mais a trapaça, até pela situação imposta pelos seus clientes. Geralmente os clientes do interior do Estado são mais receosos quando é oferecido um produto bom em conjunto com outro.

Já em relação ao fator 'empurrar um produto', nota-se que novamente os empresários e vendedores da RMC reconhecem mais a trapaça, embora com índices mais próximos. É notado que no interior é mais difícil empurrar um produto. Portanto, a hipótese $\mathrm{H} 3$ foi refutada, tendo diferença significativa em dois fatores.

\section{Análise de Variância Simples entre pequenos empresários e vendedores}

Para verificar a hipótese H4 que afirma que 'Não há diferença significativa entre as respostas de pequenos empresários e vendedores', foi feita a análise de variância entre os pequenos empresários e os vendedores. Inicialmente foi feito o teste de homogeneidade (teste de Levene), novamente com resultados acima de 0,05 , podendo continuar com o procedimento.

Brasiliana - Journal for Brazilian Studies. Vol. 2, n.2 (Nov 2013). ISSN 2245-4373. 
Quanto aos resultados, com os dados segmentados entre pequenos empresários e vendedores, verificou que o fator 1 (Crimes fiscais contra o governo e trabalhador) encontrou diferença significativa.

Analisando o fator que teve diferença significativa, 'Crimes fiscais contra o governo e trabalhador', entre empresários e vendedores, nota-se que os vendedores são os que mais reconhecem a trapaça, isto é bem compreensivo, pois os maiores prejudicados são os próprios vendedores e partindo do pressuposto que quem é mais afetado são os que mais reconhecem a trapaça este resultado só vem confirmar. Por outro lado, os empresários sendo os mais beneficiados têm maiores dificuldades no reconhecimento deste item como trapaça.

Diante do exposto a hipótese H4 foi refutada, pois houve diferença significativa no fator 'Crimes fiscais contra o governo e trabalhador'.

\section{Análise de Variância Simples entre a escolaridade}

O índice do teste de homogeneidade (teste de Levene) ficou acima do valor permitido. Com relação aos resultados, com os dados segmentados entre a escolaridade foram encontradas diferenças significativas nos fatores 3 (Comportamento abusivo em relação ao produto) e 5 (Ilegalidades Apropriação indevida).

Analisando o fator 3 (Comportamento abusivo em relação ao produto) em relação à escolaridade dos respondentes, nota-se que quanto maior o nível de escolaridade maior a capacidade de reconhecer a trapaça. Sobretudo parece haver um ponto de inflexão quando a pessoa entra no ensino superior, notando-se uma grande diferença de percepção entre as pessoas que cursam ou já cursaram o nível superior em relação às demais.

Brasiliana - Journal for Brazilian Studies. Vol. 2, n.2 (Nov 2013). ISSN 2245-4373. 
Já com relação ao fator 5 (Apropriação indevida), nota-se o mesmo comportamento do anterior, quanto maior o nível de escolaridade maior o reconhecimento da trapaça. Percebe-se, também, que quando a pessoa entra no ensino superior a percepção é refinada no reconhecimento de situação de trapaça.

Este comportamento é complacente com a realidade, visto que as pessoas que cursam o nível superior tendem a ser influenciada pelo seu contexto, mudando consequentemente suas percepções.

Para testar a hipótese H5, que afirmava que ‘há diferença significativa da percepção entre os entrevistados com escolaridade de nível superior e os demais níveis (médio, fundamental, alfabetizados e analfabetos) (Almeida, 2007)’ foi feita a Análise de Variância com os grupos que possuem nível superior e os que não possuem. O teste de homogeneidade ficou com valores acima do permitido, sendo autorizado o uso do procedimento.

Com o resultado da Análise entre estes grupos não foi verificada diferença significativa em nenhum fator, refutando a hipótese H5.

\section{Considerações Finais}

Em relação ao primeiro objetivo especifico que apontava discutir aspectos da Malandragem, entende-se tê-lo alcançado. Para tanto, foi formulada a hipótese H1 que afirmava que a malandragem é um traço da cultura e da moral brasileira, portanto, maior parte das respostas está concentrada na opção malandragem, foi verificado que a maior parte das respostas está concentrada na dimensão trapaceiro, o que consequentemente refuta esta hipótese.

Com relação ao segundo objetivo que consistia em associar as respostas em comportamentos que lesam a Coletividade e que lesam a pessoa, foi formulada a 
hipóteses H2 que dizia que o empresário e vendedor tendem a reconhecer a trapaça quando ela prejudica uma pessoa (trabalhador e cliente) e não tem a mesma clareza moral quando ela prejudica a coletividade (Pinheiro et al.,2010), foi examinado que nas questões pertinentes as práticas que lesam o cliente e o trabalhador e as que lesam o governo, os maiores índices se concentram mais na dimensão trapaceiro, refutando a hipótese.

Para propiciar uma melhor interpretação das relações entre as variáveis definidas na pesquisa, foi realizada a análise fatorial no intuito da redução da quantidade de variáveis. O alpha de Cronbach foi identificado com um bom índice de confiabilidade. Foram identificados seis fatores:

- Fator 1 - Crimes fiscais contra governo e trabalhador;

- Fator 2 - Comportamento abusivo em promoção;

- Fator 3 - Comportamento abusivo em relação ao produto;

- Fator 4 - Venda de um produto bom, casado com um produto ruim;

- Fator 5 - Apropriação indevida;

- Fator 6 - Empurrar um produto.

O terceiro objetivo que consistia em verificar se há diferenças de percepção entre os respondentes da Região Metropolitana de Fortaleza (RMF) e a Região Metropolitana do Cariri (RMC), com base no objetivo foi formatada a hipótese H3 que afirmava que não há diferença significativa entre as respostas da RMF e da RMC sobre as práticas lesivas recorrentes (trapaças), portanto, não há nesse caso, influência da cultura regional (Pinto, 2008), foi testado que:

Há diferença significativa em dois fatores: no fator 4 (Venda de um produto bom, casado com um produto ruim) e no fator 6 (Empurrar um produto), nos dois fatores 
nota-se que os empresários e vendedores do RMC reconhecem mais a trapaça que a RMF. Sendo esta hipótese refutada.

O quarto objetivo que visava identificar se há diferenças de percepção entre pequenos empresários e vendedores, com isso foi estabelecida a hipótese H4 que afirmava que não há diferença significativa entre as respostas de pequenos empresários e vendedores, foi verificado que possui diferença em apenas um fator (Crimes fiscais contra o governo e trabalhador), tendo-se verificado que os vendedores são os que mais reconhecem a trapaça. Sendo esta hipótese refutada.

O último objetivo consistia em verificar se existem percepções distintas quando se analisam as questões tendo como base as características de nível de escolaridade, sendo formatada a hipótese a H5 onde afirma que há diferença significativa da percepção entre os entrevistados com escolaridade de nível superior e os demais níveis (médio, fundamental, alfabetizados e analfabetos) (Almeida, 2007).

Esta hipótese foi refutada. No entanto se observarmos todos os níveis de escolaridade, sem fazer um corte no nível superior, nota-se que possuem diferenças significativas nos fatores 3 (Comportamento abusivo em relação ao produto) e no fator 5 (Ilegalidades Apropriação indevida). Notou-se nestes fatores que quanto maior o nível de escolaridade maior a capacidade para o reconhecimento da trapaça.

Em uma perspectiva teórica este trabalho está inserido no contexto das pesquisas que visam a apresentar contribuições em relação à Ética, cultura nacional, cultura organizacional e malandragem (ver referencial teórico), bem como metodológico com a proposição de um instrumento que visa a verificar situações corriqueiras do comércio varejista de pequeno porte. Entretanto, tem semelhanças com outros contextos do meio empresarial. 
Os resultados deste trabalho também complementam os frutos do trabalho de Pinheiro et. al., 2010, que teve como uso uma escala de mesma natureza, só que mais reduzida do que a utilizada neste trabalho.

Interessante notar que as dimensões 'pouco malandro' e 'muito malandro' foram as menos lembradas, sendo que a primeira o foi ainda menos. Acredita-se que isso se deva ao fato de que a malandragem mais característica do varejo não seja caracterizada como pouca, mas como algo que pode afetar as pessoas.

Dentro das limitações do trabalho, algumas merecem ênfase, sobretudo na amostra, que foi coletada apenas no setor de varejo de pequeno porte. Recomenda-se a aplicação do instrumento em outros setores da atividade econômica, o que deve servir para o aprimoramento do próprio instrumento.

$O$ fato de ocorrer diferenças e semelhanças de percepções entre os empresários e os vendedores da RMF e RMC investigados, não permite que essas percepções sejam as mesmas para outras regiões do Brasil.

Portanto é recomendada a aplicação do estudo em outras regiões do país, que pode ser usado como comparação com o presente estudo, compondo assim uma base e um campo de estudo capaz de engendrar novas perspectivas tendo em vista o caráter multicultural do nosso País.

Pode ser recomendada, como forma de evolução do estudo, a aplicação do estudo no futuro, quando o país passar por diversas mudanças em seu contexto econômico, social e principalmente educacional.

Por fim recomenda-se uma pesquisa preponderantemente com o método qualitativo, utilizando as dimensões do trabalho, como forma de complementação e investigação de outras indagações. 
Acredita-se que algumas destas indagações possam ser produzidas em pesquisas futuras para a melhor compreensão das dimensões do estudo no contexto brasileiro.

\section{Referências}

Almeida, Alberto C. A cabeça do brasileiro. 2. ed. Rio de Janeiro: Record, 2007.

Alves, B. F. Superpoderes, malandros e heróis: analisando o discurso da identidade nacional nos quadrinhos brasileiros de super-heróis. 2003. 123 f. Dissertação (Mestrado em Comunicação) - Programa de Pós-Graduação em Comunicação, Universidade Federal de Pernambuco, Recife, 2003.

Borja, J. A formação da cultura nacional e seus impactos na cultura das organizações do Brasil. Cientefico, Salvador, 2005, v.5, n. 1, p. 1-8. 2005.

Brasil. Constituição (1988). Constituição da República Federativa do Brasil: promulgada em 5 de outubro de 1988. Organização do texto: Juarez de Oliveira. 4. ed. São Paulo: Saraiva, 1990. 168 p. (Série Legislação Brasileira).

Brasil. Decreto-lei N. 5.452 , de $1^{\circ}$ de maio de 1943. Consolidação das leis do trabalho. Publicado no diário oficial da união em 09/08/1943.

Brasil. Decreto-lei N. o 8.078, de 11 de setembro de 1990. Dispõe sobre a proteção do consumidor e dá outras providências. Publicado no diário oficial da união em 12/09/1990.

Brasil. Decreto-lei N. LEI № 8.137 de 27 de dezembro de 1990. Define crimes contra a ordem tributária, econômica e contra as relações de consumo, e dá outras providências. Publicado no diário oficial da união em 28/12/1990.

Chu, R. A.; Wood-Jr. T. Cultura organizacional brasileira pós-globalização: global ou local? Revista de Administração Pública, Rio de Janeiro, v.42, n. 5, p. 969-991, set/out. 2008.

Brasiliana - Journal for Brazilian Studies. Vol. 2, n.2 (Nov 2013). ISSN 2245-4373. 
Corrar, L. J.; Paulo, E.; Dias-Filho, J. M. Análise multivariada: para os cursos de administração, ciências contábeis e economia. FIPECAFI. São Paulo: Atlas, 2007.

DaMatta, R. Carnavais Malandros e Heróis: para uma sociologia do dilema brasileiro. $6^{\underline{a}}$ ed. Rio de Janeiro: Rocco, 1997. . O que faz o brasil, Brasil? Rio de Janeiro: Sala, 1984.

Field. A. Descobrindo a Estatística usando o SPSS. 2. ed. Porto Alegre: Artmed, 2009.

Freitas, Alexandre Borges de. Traços brasileiros para uma análise organizacional. In: Motta, Fernando C. Prestes e Caldas, Miguel P. (org) Cultura organizacional e cultura brasileira, São Paulo: Atlas, 1997.

Freyre, Gilberto. Casa-Grande \& Senzala. Rio de Janeiro: Record, 1998.

Governo do Estado do Ceará. Decreto n. 29.569, de 31 de Julho de 1997. Consolida e regulamenta a legislação do imposto sobre operações relativas à circulação de mercadorias e sobre prestações de serviços de transporte interestadual e intermunicipal e de comunicação (ICMS), e dá outras providências. Publicado no diário oficial do estado em 04/08/1997.

Holanda, S. B. Raízes do Brasil. São Paulo: Cia das Letras, 2006.

Houaiss, A. (Ed). Enciclopédia e dicionário digital 2010.

Malhotra, Naresh K. Pesquisa de Marketing - uma orientação aplicada. 4. ed. Porto Alegre: Bookman, 2006.

Moreira, P. M. Entre a justiça e o sofrimento: um estudo nas empresas do comércio varejista de fortaleza. 2007. 127 F. Dissertação (Mestrado em Administração) Universidade Estadual do Ceará, Fortaleza, 2007.

Pinheiro, D. R. C.; Lôbo, R. J. S.; Câmara, S. F.; Silva, L. F. S.; Lima, F. A. S. Esperteza, Malandragem e Trapaça: Estratégias Tradicionais de Relacionamento com Coletividade e Indivíduo. In: Encontro de Estudos sobre Empreendendorismo e Gestão de Pequenas Empresas - EGEPE, 6, Recife, 2010. Anais eletrônicos. Recife: EGEPE, 2010. 1 CD ROM. 
Pinto, F. R. Evasão Fiscal e Estratégia Empresarial: A Percepção de Empresários Brasileiros. 2008. 268 f. Tese (Doutorado em Gestão de Empresas) - Faculdade de Economia, Universidade de Coimbra, Coimbra, 2008.

Pires, J. C. S.; Macêdo, K. B. Cultura organizacional em organizações públicas no Brasil. Revista de Administração Pública, Rio de Janeiro, v.40, n. 1, p. 81-104, jan/fev. 2006.

Rocha, G. Eis o malandro na praça outra vez": a fundação da discursividade malandra no Brasil dos anos 70. SCRIPTA, Belo Horizonte, v. 10, n. 19, p. 108-121, 2006. 